\title{
PEMBELAJARAN GI DAN GI-PROBLEM POSING (GI-PP) PADA MATA KULIAH KALKULUS LANJUT DITINJAU DARI SIKAP MAHASISWA TERHADAP MATEMATIKA
}

\author{
Swasti Maharani ${ }^{1)}$ \\ ${ }^{1}$ FPMIPA, IKIP PGRI Madiun \\ email: swastimaharani@yahoo.com
}

\begin{abstract}
The objectives of this research were to find out: (1) which learning model of the GI or GIProblemPosing results in a better learning achievement; (2) which students' attitudes of the positive, neutral, or negative types results in a better learning achievement; (3) in each students' attitudes, which learning model of the GI or GI-Problem Posing results in a better learning achievement; and (4) in each learning model, which students' attitudes of the positive, neutral, or negative types results in a better learning achievement.

This research used the quasi experimental research method with the factorial design of $2 x 3$. Its population was all of the students of Mathematics department of IKIP PGRI Madiun in academic year 2014/2015. The samples were taken by using the random sampling technique. The data were gathered through test and questionnaire method and its were analyzed by using the unbalanced twoway analysis of variance at the significance level of 5\%.

The results showed that: (1) the GI and GI-ProblemPosing result in the same good learning achievement; (2) the learning achievement with positive was better than that with neutral and negative, that with neutral was better than that with negative; (3) in each students' attitudes type, the GI and GI-ProblemPosing result in the same good learning achievement; (4) in general, the learning achievement with positive was better than neutral and negative, that neutral was better than negative. However, if viewed from GI with a positive and neutral have the same achievement and better than negative.
\end{abstract}

Keywords: learning model, GI, Problem Posing, students attitudes towards Mathematics.

\section{PENDAHULUAN}

Secara umum kondisi pembelajaran

Matematika di IKIP PGRI Madiun khususnya pada Program Studi Pendidikan Matematika belum sesuai harapan. Hal tersebut terlihat pada nilai rata-rata UAS pada mata kuliah Kalkulus Lanjut tahun 2013 masih rendah yaitu 68 . Di dalam pembelajaran terdapat banyak faktor yang mempengaruhi keberhasilan belajar, baik faktor intern maupun ekstern. Salah satu faktor yang mempengaruhi keberhasilan belajar Matematika adalah sikap mahasiswa terhadap Matematika. Borasi (dalam Mohd and Farah, 2011) berpendapat "The conceptions, attitudes, and expectations of students regarding mathematics and mathematics teaching have been considered to be very significant factor underlying their school experience and achievement”. Konsepsi, sikap, dan harapan siswa tentang matematika dan pembelajaran matematika telah dianggap sebagai faktor yang sangat penting yang mendasari pengalaman dan prestasi mereka di sekolah. 
Meskipun belajar merupakan konstruksi kognitif yang dialami oleh masing-masing mahasiswa, tetapi dalam prosesnya mahasiswa tidak dapat lepas dari sikap mahasiswa terhadap matematika. Oleh karena itu diperlukan adanya upaya perubahan dalam bidang pembelajaran matematika terutama pada model pembelajaran matematika. Model pembelajaran yang diperlukan adalah model pembelajaran yang dapat membuat matematika menjadi lebih menarik bagi mahasiswa. Model Pembelajaran Kooperatif tipe GI dan GI-Problem Posing yang melibatkan mahasiswa sejak perencanaan, baik dalam menentukan subtopik maupun cara untuk mempelajarinya melalui investigasi serta meningkatkan kreatifitas mahasiswa menarik untuk diteliti.

Adapun tujuan dari penelitian ini adalah sebagai berikut :

1. Untuk menentukan apakah terdapat perbedaan prestasi belajar mahasiswa pada model pembelajaran GI dan GIProblem Posing pada pokok bahasan integral lipat dua.

2. Untuk menentukan apakah terdapat perbedaan prestasi mahasiswa yang mempunyai sikap positif, netral atau negatif tehadap matematika pada pokok bahasan integral lipat dua.
3. Untuk menentukan manakah yang mempunyai prestasi belajar lebih baik antara mahasiswa yang diberikan model pembelajaran GI atau GIProblem Posing pada masing-masing kategori sikap mahasiswa terhadap matematika yaitu sikap positif, netral dan negatif terhadap matematika.

4. Untuk menentukan manakah mahasiswa yang mempunyai prestasi belajar lebih baik antara mahasiswa dengan sikap positif, netral atau negatif terhadap matematika pada masingmasing pembelajaran yaitu model pembelajaran GI dan GI-Problem Posing.

\section{METODE PENELITIAN}

Penelitian ini merupakan penelitian eksperimental semu dengan desain faktorial 2x3. Analisis data dilakukan dengan Anava dua jalan dengan sel tak sama dengan taraf signifikansi $5 \%$. Populasi penelitian adalah mahasiswa semester 4 Pendidikan Matematika IKIP PGRI Madiun tahun akademik 2014/2015. Sampel diambil secara random sampling dan terpilih 2 kelas yaitu kelas kontrol (pembelajaran GI) dan kelas eksperimen (pembelajaran GIProblem Posing).

Uji normalitas menggunakan metode Lilliefors dan diperoleh hasil bahwa kedua kelompok berasal dari populasi 
yang berdistribusi normal. Hal tersebut dapat dilihat pada Tabel 1 berikut.

Tabel 1. Rangkuman Hasil Uji

Normalitas untuk Data Nilai

Kemampuan Awal

\begin{tabular}{|c|c|c|c|c|}
\hline $\begin{array}{c}\text { Pembelaj } \\
\text { aran }\end{array}$ & $L \mathrm{Obs}$ & $\begin{array}{c}L \\
\text { Kritik }\end{array}$ & $\begin{array}{l}\text { Keputu } \\
\text { san Uji }\end{array}$ & $\begin{array}{c}\text { Data } \\
\text { berdistri } \\
\text { busi }\end{array}$ \\
\hline GI & 0,0893 & 0,135 & $\begin{array}{c}H_{0} \\
\text { diterima }\end{array}$ & Normal \\
\hline $\begin{array}{c}\text { GI- } \\
\text { Problem } \\
\text { Posing }\end{array}$ & 0,0718 & 0,135 & $\begin{array}{c}H_{0} \\
\text { diterima }\end{array}$ & Normal \\
\hline
\end{tabular}

uji homogenitas variansi antar kedua kelompok sampel dengan menggunakan uji $\mathrm{F}$ dan diperoleh $\mathrm{F}$ observasi $=1,5601, \mathrm{~F}$ tabel sebesar 1,7049. Karena F Observasi $=1,5601<1,7049=\mathrm{F}$ tabel, maka keputusan uji nya $H_{0}$ diterima, sehingga dapat disimpulkan bahwa populasi mahasiswa antar model pembelajaran mempunyai variansi populasi yang bersifat homogen. Sedangkan uji keseimbangan antara kedua kelompok tersebut dengan uji t. Sehingga diperoleh nilai t observasi sebesar $-4,839$ dan $t$ tabel sebesar 1,645, sehingga dapat disimpulkan bahwa kedua kelompok berada dalam keadaan seimbang.

Teknik pengumpulan data adalah metode angket dan tes. Instrumen penelitian adalah tes prestasi dan angket sikap mahasiswa terhadap matematika.

Variabel terikat adalah prestasi belajar matematika pada pokok bahasan integral lipat-3, sedangkan variabel bebasnya adalah model pembelajaran yang terbagi atas model pembelajaran GI pada kelas kontrol dan model pembelajaran GIProblem Posing pada kelas eksperimen. Variabel bebas yang lain adalah sikap mahasiswa terhadap matematika dengan kategori sikap positif, netral dan negatif terhadap matematika.

Uji prasyarat analisis yaitu uji normalitas dengan metode Lilliefors dan uji homogenitas dengan uji Bartlett. Diperoleh prasyarat normalitas dan homogenitas data telah terpenuhi, sehingga dapat dilakukan analisis data menggunakan anava dua jalan dengan sel tak sama dan uji komparasi ganda menggunakan metode Scheffe'. Uji Normalitas dan homogenitas dapat dilihat pada Tabel 2 dan Tabel 3 berikut.

Tabel 2. Rangkuman Hasil Uji Normalitas

\begin{tabular}{ccccc}
\hline $\begin{array}{c}\text { Populasi } \\
\text { Siswa }\end{array}$ & Obs & $\begin{array}{c}L \\
\text { Kritik }\end{array}$ & $\begin{array}{c}\text { Keputusan } \\
\text { Uji }\end{array}$ & $\begin{array}{c}\text { Data } \\
\text { Berdistri } \\
\text { busi }\end{array}$ \\
\hline $\begin{array}{c}\text { GI } \\
\text { GI-Problem } \\
\text { Posing }\end{array}$ & 0,0726 & 0,1351 & $H_{0}$ diterima & Normal \\
Sikap & 0,0704 & 0,1351 & $H_{0}$ diterima & Normal \\
$\begin{array}{c}\text { Positif } \\
\text { Sikap Netral } \\
\text { Sikap }\end{array}$ & 0,0812 & 0,1765 & $H_{0}$ diterima & Normal \\
Negatif & 0,1362 & 0,1765 & $H_{0}$ diterima & Normal \\
\hline
\end{tabular}

Tabel 3. Rangkuman Hasil Uji Homogenitas Variansi 


\section{HASIL DAN PEMBAHASAN}

Rangkuman hasil analisis anava dua jalan dapat dilihat pada Tabel 4 dan rangkuman komparasi ganda dapat dilihat pada Tabel 5 dan Tabel 6.

Tabel 4. Rangkuman Analisis Variansi Dua Jalan

\begin{tabular}{|c|c|c|c|c|c|c|}
\hline Sumber & $J K$ & $d k$ & $R K$ & $F_{o b s}$ & $F_{\text {tabel }}$ & $\begin{array}{r}\text { Keputus } \\
\text { an Uji }\end{array}$ \\
\hline $\begin{array}{c}\text { Pembela } \\
\text { jaran } \\
\text { (A) }\end{array}$ & 4712,77 & 1 & 4712,77 & 41,53 & 3,987 & $\begin{array}{c}H_{0} \\
\text { ditolak }\end{array}$ \\
\hline $\begin{array}{l}\text { Sikap } \\
(B)\end{array}$ & 1963,04 & 1 & 1963,04 & 17,30 & 3,987 & $\begin{array}{c}H_{0} \\
\text { ditolak }\end{array}$ \\
\hline $\begin{array}{c}\text { Interaksi } \\
(A B)\end{array}$ & 308,188 & 1 & 308,19 & 2,72 & 3,987 & $\begin{array}{c}H_{0} \\
\text { diterima }\end{array}$ \\
\hline Galat & 7943,59 & 70 & 113,48 & - & - & \\
\hline Total & $\begin{array}{c}14927,5 \\
9\end{array}$ & 73 & - & - & - & \\
\hline
\end{tabular}

Tabel 5. Rangkuman Uji Komparasi Ganda Antar Kolom

\begin{tabular}{|c|c|c|c|c|}
\hline $\begin{array}{c}\text { Komparasi } \\
\text { antar sikap } \\
\text { mahasiswa } \\
\text { terhadap } \\
\text { matematika } \\
\end{array}$ & $H_{0}$ & $F_{o b s}$ & $F_{\text {kritis }}$ & $\begin{array}{c}\text { Keputus } \\
\text { an }\end{array}$ \\
\hline $\begin{array}{c}\text { Positif } \\
\text { dengan } \\
\text { Netral }\end{array}$ & $\mu_{\cdot 1}=\mu_{\cdot 2}$ & 28,2430 & 6,247 & $\begin{array}{c}H_{0} \\
\text { Ditolak }\end{array}$ \\
\hline $\begin{array}{l}\text { Positif } \\
\text { dengan } \\
\text { Negatif }\end{array}$ & $\mu_{\cdot 1}=\mu_{\cdot 3}$ & 145,469 & 6,247 & $\begin{array}{c}H_{0} \\
\text { Ditolak }\end{array}$ \\
\hline $\begin{array}{l}\text { Netral } \\
\text { dengan } \\
\text { Negatif }\end{array}$ & $\mu_{\cdot 2}=\mu_{\cdot 3}$ & 41,9614 & 6,247 & $\begin{array}{c}H_{0} \\
\text { Ditolak }\end{array}$ \\
\hline
\end{tabular}

Tabel 6. Rangkuman Uji Komparasi Ganda Antar Sel

\begin{tabular}{cccc}
\hline$H_{0}$ & $F_{\text {obs }}$ & $5 F_{0,05 ; 5 ; 80}$ & $\begin{array}{c}\text { Kesimpul } \\
\text { an }\end{array}$ \\
\hline$\mu_{11}=\mu_{21}$ & 0,9225 & $(5)(2,34)=11,7$ & Diterima \\
$\mu_{12}=\mu_{22}$ & 2,1226 & $(5)(2,34)=11,7$ & Diterima \\
$\mu_{13}=\mu_{23}$ & 6,6917 & $(5)(2,34)=11,7$ & Diterima
\end{tabular}

Berdasarkan Tabel 5., diperoleh $\mathrm{H}_{0}$ pada uji antara kolom pertama dan kedua ditolak, maka terdapat perbedaan signifikan antara rataan marginal untuk kelompok mahasiswa dengan sikap positif terhadap matematika sebesar 71,75 dengan kelompok mahasiswa dengan sikap netral terhadap matematika sebesar 61,74, maka dapat disimpulkan bahwa prestasi belajar matematika mahasiswa dengan sikap positif terhadap matematika lebih baik daripada prestasi belajar matematika mahasiswa dengan sikap netral terhadap matematika.

$\mathrm{H}_{0}$ pada uji antara kolom pertama dan ketiga ditolak, maka terdapat perbedaan signifikan antara rataan marginal untuk kelompok mahasiswa dengan sikap positif terhadap matematika sebesar 71,75 dengan kelompok mahasiswa dengan sikap negatif terhadap matematika sebesar 49,03, maka dapat disimpulkan bahwa 
prestasi belajar matematika mahasiswa dengan sikap positif terhadap matematika lebih baik daripada prestasi belajar matematika mahasiswa dengan sikap negatif terhadap matematika.

$\mathrm{H}_{0}$ pada uji antara kolom kedua dan ketiga ditolak, maka terdapat perbedaan signifikan antara rataan marginal untuk kelompok mahasiswa dengan sikap netral terhadap matematika sebesar 61,74 dengan kelompok mahasiswa dengan sikap negatif terhadap matematika sebesar 49,03, maka dapat disimpulkan bahwa prestasi belajar matematika mahasiswa dengan sikap netral terhadap matematika lebih baik daripada prestasi belajar matematika mahasiswa dengan sikap negatif terhadap matematika.

Berdasarkan uraian, dapat disimpulkan bahwa prestasi belajar matematika mahasiswa dengan sikap positif terhadap matematika lebih baik daripada prestasi belajar matematika mahasiswa dengan sikap netral maupun negatif terhadap matematika. Prestasi belajar matematika mahasiswa dengan sikap netral terhadap matematika lebih baik daripada prestasi belajar matematika mahasiswa dengan sikap negatif terhadap matematika.

Berdasarkan tabel 5.9. dapat diuraikan sebagai berikut:
(1) Tidak terdapat perbedaan prestasi belajar mahasiswa dengan model pembelajaran kooperatif tipe GI dan mahasiswa dengan model pembelajaran kooperatif tipe GI dengan pendekatan Problem Posing.

(2)Untuk mahasiswa yang diberi pembelajaran dengan model pembelajaran GI, mereka yang mempunyai sikap positif dan netral terhadap matematika mendapatkan prestasi yang sama dan lebih baik daripada mahasiswa dengan sikap negatif terhadap matematika.

(3)Untuk mahasiswa yang diberi pembelajaran dengan model pembelajaran GI-Problem Posing, tidak ada perbedaan prestasi belajar antara mahasiswa dengan sikap positif,netral dan negatif terhadap matematika.

Hasil penelitian adalah sebagai berikut:

1. Tidak terdapat perbedaan prestasi belajar mahasiswa dengan model pembelajaran kooperatif tipe GI dan mahasiswa dengan model pembelajaran kooperatif tipe GI dengan pendekatan Problem Posing pada pokok bahasan integral lipat dua.

2. Prestasi belajar matematika mahasiswa dengan sikap positif terhadap matematika lebih baik daripada 
prestasi belajar matematika mahasiswa dengan sikap netral maupun negatif terhadap matematika. Prestasi belajar matematika mahasiswa dengan sikap netral terhadap matematika lebih baik daripada prestasi belajar matematika mahasiswa dengan sikap negatif terhadap matematika.

3. Pada masing-masing sikap mahasiswa terhadap matematika tidak terdapat perbedaan prestasi belajar mahasiswa dengan model pembelajaran kooperatif tipe GI dan mahasiswa dengan model pembelajaran kooperatif tipe GI dengan pendekatan Problem Posing pada pokok bahasan integral lipat dua.

4. Secara umum prestasi belajar matematika mahasiswa dengan sikap positif terhadap matematika lebih baik daripada prestasi mahasiswa dengan sikap netral maupun negatif terhadap matematika dan prestasi mahasiswa dengan sikap netral terhadap matematika lebih baik daripada prestasi belajar matematika mahasiswa dengan sikap negatif terhadap matematika. Namun demikian, kalau ditinjau secara khusus pada model pembelajaran GI mereka yang mempunyai sikap positif dan netral terhadap matematika mendapatkan prestasi yang sama dan lebih baik daripada mahasiswa dengan sikap negatif terhadap matematika.

\section{KESIMPULAN}

Berdasarkan kajian teori dan didukung adanya analisis serta mengacu pada perumusan masalah yang telah diuraikan, dapat disimpulkan beberapa hal berikut.

1. Tidak terdapat perbedaan prestasi belajar mahasiswa dengan model pembelajaran kooperatif tipe GI dan mahasiswa dengan model pembelajaran kooperatif tipe GI dengan pendekatan Problem Posing pada pokok bahasan integral lipat dua.

2. Prestasi belajar matematika mahasiswa dengan sikap positif terhadap matematika lebih baik daripada prestasi belajar matematika mahasiswa dengan sikap netral maupun negatif terhadap matematika. Prestasi belajar matematika mahasiswa dengan sikap netral terhadap matematika lebih baik daripada prestasi belajar matematika mahasiswa dengan sikap negatif terhadap matematika.

3. Pada masing-masing sikap mahasiswa terhadap matematika tidak terdapat perbedaan prestasi belajar mahasiswa dengan model pembelajaran kooperatif tipe GI dan mahasiswa dengan model pembelajaran kooperatif tipe GI dengan pendekatan Problem Posing pada pokok bahasan integral lipat dua. 
4. Secara umum prestasi belajar matematika mahasiswa dengan sikap positif terhadap matematika lebih baik daripada prestasi mahasiswa dengan sikap netral maupun negatif terhadap matematika dan prestasi mahasiswa dengan sikap netral terhadap matematika lebih baik daripada prestasi belajar matematika mahasiswa dengan sikap negatif terhadap matematika. Namun demikian, kalau ditinjau secara khusus pada model pembelajaran GI mereka yang mempunyai sikap positif dan netral terhadap matematika mendapatkan prestasi yang sama dan lebih baik daripada mahasiswa dengan sikap negatif terhadap matematika.

\section{DAFTAR PUSTAKA}

.(http://pmat.uad.ac.id/pendeka tan-pembelajaran-problemposing.html)

Akinsola, M. K. and Olowojaiye, F. B. 2008. Teacher Instructional Methods and Student Attitudes Towards Mathematics. International Electronic Journal of Mathematics Education. 3(1): 60-73.

Amirali, M. 2010. Students' Conceptions of the Nature of Mathematics and Attitudes towards Mathematics Learning. Journal of Research and Reflections in Education, 4(1): 27-41.
Budiyono. 2003. Metodologi Penelitian Pendidikan.Surakarta: Sebelas Maret University Press.

Budiyono. 2009. Statistika Untuk Penelitian. Surakarta: Sebelas Maret University Press.

Departemen Pendidikan dan Kebudayaan. 2005. Kamus Besar Bahasa Indonesia. Jakarta: Balai Pustaka.

Hamzah B.Uno. 2007. Model Pembelajaran. Gorontalo: Bumi Aksara.

Herman Hudojo. 2005. Kapita Selekta Pembelajaran Matematika. Malang: UM Press.

Mohd, N. and Farah, T. 2011. The effects of Attitude Towards Problem Solving in Mathematics Achievements. Australian Journal of Basic and Applied Sciences, 5(12): 1857-1862.

Reni Akbar Hawadi. 2004. Akselerasi. Jakarta: PT Gramedia Widia Sarana Indonesia.

Rusgianto. 2006. Hubungan Antara Sikap Terhadap Matematika, Kecerdasan Emosional Dalam Interaksi Sosial Di Kelas Dengan Hasil Belajar Matematika Siswa Smp Negeri 5 Yogyakarta Tahun 2006. Makalah yang disampaikan pada Seminar Nasional Matematika dan Pendidikan Matematika 2006 dengan tema "Trend Penelitian dan Pembelajaran Matematika di Era ICT “ yang diselenggarakan pada tanggal24 Nopember 2006.

Saifuddin Azwar. 2012. Sikap Manusia Teori dan pengukurannya.Yogyakarta: Pustaka Pelajar.

Siti Munjiyatun Aly. 2009. Pengaruh Model Pembelajaran Kooperatif Tipe 
Student Teams Achievement Division (STAD) Dan Tipe Group Investigation (GI) Terhadap Prestasi Belajar Matematika Ditinjau Dari Kreativitas Siswa. Tesis PPs UNS.
Wina Sanjaya. 2008. Strategi Pembelajaran Berorientasi StandarProses Pendidikan .Jakarta: Kencana Prenada Media Group. 